\title{
STUDI LIKUIDITAS PASAR SAHAM TERKAIT PERUBAHAN KELOMPOK HARGA DAN FRAKSI HARGA SAHAM DI BURSA EFEK INDONESIA
}

\section{STUDY OF STOCK MARKET LIQUIDITY RELATED TO CHANGE IN GROUP PRICE AND TICK SIZE IN INDONESIA STOCK EXCHANGE}

\author{
Dahlia Ervina $^{*}$ 1 dan Rathria Arrina Rachman*) \\ *) Sekolah Bisnis dan Ekonomi, Universitas Prasetiya Mulya \\ Jl. BSD Raya Utama, BSD City, Tangerang 15339
}

\begin{abstract}
The Indonesia Stock Exchange (IDX) imposed a new policy of tick size and price category changes in 2016. The purpose is to increase liquidity in order to improve the competitiveness of the capital market in Indonesia. This study aims to determine the effectiveness of the IDX's new policy in 2016 by analyzing whether changes follow the new policy applying changes in tick size and price category in the liquidity of the Indonesian stock market. In this study, stock market liquidity was measured by using the bid-ask spread, market-depth, and stock trading volume. This study applied an event study approach by including all shares traded on the Indonesia Stock Exchange (IDX) for the period of 40 days before to 40 days after the week of the new policy enforcement. The research found differences in bid-ask spread, market-depth, and stock trading volume for the period before and after the new policy applied. In conclusion, there were no significant differences in stock market liquidity after the change in policy.
\end{abstract}

Keywords: stock exchange, tick size, price categories, stock liquidity, stock volume

\begin{abstract}
Abstrak: Bursa Efek Indonesia (BEI) memberlakukan kebijakan baru perubahan fraksi harga dan kelompok harga saham pada tahun 2016. Hal ini dilakukan untuk meningkatkan likuiditas yang dapat meningkatkan daya saing pasar modal di Indonesia. Penelitian ini bertujuan untuk mengetahui efektivitas kebijakan baru BEI pada tahun 2016 dengan menganalisis apakah kebijakan baru yang mengubah kelompok harga dan fraksi harga saham tersebut diikuti dengan perubahan likuiditas pasar saham di Indonesia. Dalam penelitian ini, likuiditas pasar saham diukur dengan menggunakan bid-ask spread, market-depth dan volume perdagangan saham. Penelitian ini menggunakan pendekatan event study dengan mengikutsertakan seluruh saham yang diperdagangkan di Bursa Efek Indonesia (BEI) untuk periode 40 hari sebelum hingga 40 hari setelah minggu dimana pemberlakukan kebijakan baru. Temuan penelitian menemukan tidak terdapat perbedaan bid-ask spread, market-depth dan volume perdagangan saham pada periode sebelum dan sesudah perubahan kebijakan, sehingga dapat disimpulkan tidak terdapat perbedaan yang signifikan dalam likuiditas pasar saham setelah perubahan kebijakan.
\end{abstract}

Kata kunci: bursa efek, fraksi harga saham, kelompok harga saham, likuiditas saham, volume saham

\footnotetext{
${ }^{1}$ Corresponding author:

Email: dahlia.ervina@pmbs.ac.id
} 


\section{PENDAHULUAN}

Pasar modal sebagai salah satu unsur pendukung perekonomian suatu negara memiliki peran penting dalam perkembangannya. Dengan adanya globalisasi, pasar modal suatu negara akan bersaing dengan pasar modal negara lain dalam menarik pelaku pasar baik investormaupun emiten. Untuk meningkatkan daya saing, pasar modal suatu negara melakukan berbagai strategi dalam mengembangkan struktur, regulasi dan teknologi yang memudahkan dan menciptakan nilai tambah bagi pelaku pasar. Salah satu strategi yang dilakukan adalah dengan meningkatkan likuiditas pasar modal sehingga biaya transaksi yang dialami oleh pelaku pasar menjadi semakin rendah.

Bursa Efek Indonesia (BEI) berfungsi untuk menyelenggarakan perdagangan efek yang teratur, wajar dan efisien, serta wajib menyediakan sarana pendukung dan mengawasi kegiatan anggota bursa. BEI juga wajib menetapkan peraturan mengenai hal-hal yang berkaitan dengan kegiatan bursa, termasuk di dalamnya mengenai kelompok harga saham dan fraksi harga saham dalam perdagangan saham. Visi dari BEI adalah menjadi bursa yang kompetitif dengan kredibilitas tingkat dunia. Sedangkan, misi dari BEI adalah menciptakan daya saing untuk menarik investor dan emiten, melalui pemberdayaan anggota bursa dan partisipan, penciptaan nilai tambah, efisiensi biaya serta penerapan good governance.

Untuk mencapai visi dan misi tersebut, maka sangat penting bagi BEI untuk melakukan strategi-strategi yang dapat menjadikan pasar modal di Indonesia efisien sehingga memiliki daya tarik bagi investor dan emiten. Bursa Efek Indonesia kembali melakukan perubahan kelompok harga dan fraksi harga saham baru terhitung mulai tanggal 2 Mei 2016. Perubahan tersebut dapat dilihat pada Tabel 1. Menurut Direktur Utama BEI, Tito Sulistio, perubahan kebijakan ini ditujukan untuk meningkatkan likuiditas dan kapitalisasi pasar serta meningkatkan daya saing bursa (pasar modal) di Indonesia (Aliya, 2016).

Perubahan kelompok harga dan fraksi harga saham sebelumnya terjadi pada 2 Januari 2014. Jarak waktu antar perubahan kelompok harga dan fraksi harga saham ini sangat singkat dibandingkan dengan perubahan sebelumnya yang terjadi pada tahun 2007. Perbedaan antara perubahan kebijakan tahun 2014 dan sebelumnya dengan kebijakan tahun 2016 juga terlihat dari kebijakan keputusan terhadap fraksi harga saham. Pada tahun 2014, secara keseluruhan fraksi harga pada seluruh kelompok harga saham mengalami penurunan, begitu juga pada kebijakan-kebijakan sebelumnya, meski penurunan fraksi harga tidak pada seluruh kelompok harga. Sedangkan, pada perubahan kebijakan di tahun 2016, fraksi harga mengalami kenaikan pada kelompok harga antara Rp200 hingga kurang dari Rp500 dan kelompok harga antara Rp2.000 hingga kurang dari Rp5.000.

Terdapat penelitian-penelitian yang telah mencoba menguji apakah kebijakan perubahan kelompok harga dan fraksi harga saham mampu meningkatkan likuiditas pasar modal. Penelitian-penelitian yang ada memberikan hasil yang beragam. Di Indonesia, Irawan dan Suaryana (2016) menemukan bahwa likuiditas perdagangan saham meningkat ditandai dengan meningkatnya aktivitas volume perdagangan saham. Endri (2016) menemukan penurunan bid-ask spread yang menandakan peningkatan likuiditas tidak diikuti oleh peningkatan volume perdagangan. Di negara lain, Aitken dan Forde (2005) dan Ahn et al. (2007) menemukan, bahwa di Australia dan Jepang, saham dengan fraksi harga yang lebih besar mengalami peningkatan likuiditas dengan adanya penurunan fraksi harga, namun hal ini tidak berlaku pada saham dengan fraksi harga yang kecil. Goldstein, dan Kavajecz (2000) menemukan penurunan fraksi harga saham di New York Stock Exchange mengakibatkan penurunan bid-ask spread yang menandakan peningkatan likuiditas, namun juga terdapat penurunan market-depth yang menandakan penurunan likuiditas saham.

Selain hasil yang beragam, perbedaan kebijakan yang diambil oleh BEI, yaitu menaikkan fraksi harga sebagian saham untuk meningkatkan likuiditas, menarik untuk diteliti, dikarenakan penelitian-penelitian sebelumnya berpusat pada dampak penurunan fraksi harga saham pada likuiditas. Penelitian ini diharapkan mampu menjawab dan menarik kesimpulan mengenai efektivitas perubahan kelompok harga dan fraksi harga saham terhadap likuiditas, terutama di pasar modal Indonesia.

Menurut Aitken dan Forde (2003), likuiditas, melalui biaya transaksi implisit, dapat diukur dalam 2 kategori yaitu pengukuran likuiditas berdasarkan transaksi dan pengukuran likuiditas berdasarkan pemesanan (order). Pengukuran berdasarkan transaksi mengukur likuiditas dari sisi telah terjadinya transaksi. Pengukuran berdasarkan pemesanan memperhitungkan semua pemesanan, baik yang menjadi suatu transaksi maupun tidak menjadi suatu transaksi. 
Tabel 1. Kelompok harga dan fraksi harga saham sebelum dan sesudah 2 Mei 2016

\begin{tabular}{lcc}
\hline Kelompok Harga & Fraksi Harga & Maksimum Perubahan \\
\hline Sebelum 2 Mei 2016 & & \\
\hline$<$ Rp500,- & Rp1,- & Rp20,- \\
Rp500,- $<$ Rp5.000,- & Rp5,-- & Rp100, \\
$>=$ Rp5.000,- & Rp25,- & Rp500,- \\
\hline Sesudah 2 Mei 2016 & & Rp10,- \\
\hline$<$ Rp200,- & Rp1,- & Rp20,- \\
Rp200,- $<$ Rp500,- & Rp2,- & Rp50,- \\
Rp500,- $<$ Rp2.000,- & Rp5 & Rp100,- \\
Rp2.000,- $<$ Rp5.000,- & Rp10,- & Rp250,- \\
$>=$ Rp5.000,- & Rp25,- & \\
\hline
\end{tabular}

Sumber: BEI, 2016.

Pengukuran berdasarkan transaksi umum dilakukan dalam penelitian-penelitian terdahulu. Umumnya variabel yang digunakan adalah volume transaksi, nilai transaksi atau jumlah transaksi. Menurut $\mathrm{Hu}$ (2009) ukuran biaya transaksi implisit dapat diklasifikasikan secara garis besar menjadi 3 kelompok: ukuran pretrade, during-trade dan post-trade. Pengukuran pretrade menggunakan harga-harga sebelum terjadinya transaksi (Perold,1988), umumnya harga penutupan hari sebelumnya. Pengukuran during-trade menggunakan harga rata-rata selama horison perdagangan, umumnya adalah volume weigthed average prive (VWAP) (Berkowitz et al. 1988). Pengukuran post-trade menggunakan harga-harga setelah perdagangan, umumnya harga penutupan dari horison perdagangan.

Pengukuran berdasarkan pemesanan dapat mengukur biaya yang terasosiasi dengan transaksi dengan lebih akurat. Salah satu jenis pengukuran ini adalah bid-ask spread. Ini adalah rentang biaya yang harus dibayar oleh investor untuk dapat langsung membeli (menjual) suatu saham sehingga tidak perlu melalui antrian. Agar pengukuran menjadi lebih tepat, diperlukan analisis jumlah pesanan dalam bid-ask spread tersebut, yang dapat mengukur kedalaman pasar (market depth).

Beberapa penelitian terdahulu menemukan peningkatan likuiditas saham dengan adanya perubahan fraksi maupun kelompok harga saham. Penelitian Harris (1994) adalah yang pertama dalam menguji dampak dari perubahan fraksi harga saham terhadap likuiditas yang diukur dengan menggunakan bid-ask spread yang merupakan parameter dari biaya transaksi. Penelitian tersebut menemukan bahwa penurunan pada fraksi harga saham cenderung menghasilkan penurunan bidask spread dan meningkatkan volume perdagangan.
Lau dan McInish (1995) melakukan penelitian dampak penurunan fraksi harga terhadap biaya transaksi di pasar modal Singapura dan menemukan bahwa penurunan fraksi harga menurunkan bid-ask spread secara signifikan yang menandakan berkurangnya biaya transaksi. Porter dan Weaver (1997) melakukan penelitian di pasar modal Kanada mengenai dampak penurunan fraksi harga terhadap kualitas pasar menemukan bahwa biaya eksekusi transaksi berkurang bagi saham dengan fraksi harga rendah dengan volume tinggi dan terjadi penurunan market depth.

Beberapa penelitian terdahulu menemukan hasil yang beragam dengan adanya peningkatan likuiditas pada satu pengukuran namun tidak pada pengukuran yang lain. Aitken dan Forde (2005) melakukan penelitian di pasar modal Australia dan menemukan bahwa saham dengan fraksi harga yang lebih besar mengalami peningkatan likuiditas dengan adanya penurunan fraksi harga, namun hal ini tidak berlaku pada saham dengan fraksi harga yang kecil. Aitken dan Forde (2005) juga menemukan tidak terdapat bukti terjadinya kenaikan volume perdagangan karena penurunan fraksi harga. Ahn et al. (2007) menemukan hal yang sama dengan perubahan fraksi harga saham di Tokyo Stock Exchange. Bessembinder (2000) melakukan penelitian di bursa Nasdaq, Amerika Serikat, dan menemukan bahwa saham dengan fraksi harga lebih kecil memiliki bid-ask spread yang lebih rendah namun tidak ditemukan penurunan likuiditas terkait perubahan fraksi harga. Goldstein dan Kavajecz (2000) menemukan penurunan fraksi harga saham di New York Stock Exchange mengakibatkan penurunan bidask spread yang menandakan peningkatan likuiditas, tetapi juga terdapat penurunan market-depth yang menandakan penurunan likuiditas saham. 
Di Indonesia, Ekaputra dan Ahmad (2007) menghasilkan temuan yang sama dengan Goldstein dan Kavajecz (2000). Sebaliknya, penelitian atas perubahan kelompok harga dan fraksi harga saham yang terbaru adalah atas perubahan kebijakan pada 2 Januari 2014. Irawan dan Suaryana (2016) menemukan bahwa likuiditas perdagangan saham meningkat ditandai dengan meningkatnya aktivitas volume perdagangan saham. Endri (2016) menemukan penurunan bid-ask spread yang menandakan peningkatan likuiditas tidak diikuti oleh peningkatan volume perdagangan.

Hasil penelitian yang beragam menyebabkan tidak dapat diambilnya kesimpulan atas efektivitas perubahan kelompok harga dan fraksi harga saham terhadap likuiditas. Bahkan, penelitian di Indonesia sendiri menghasilkan temuan yang berbeda-beda. Selain itu, faktor perbedaan kebijakan 2 Mei 2016 yang berbeda dari kebijakan-kebijakan sebelumnya yang pernah diteliti, yaitu berupa kenaikan fraksi harga pada beberapa kelompok harga, dan bukan penurunan, dengan tujuan yang sama untuk meningkatkan likuiditas pasar modal, menarik untuk diteliti. Penelitian ini diharapkan mampu menjawab dan menarik kesimpulan mengenai efektivitas perubahan kelompok harga dan fraksi harga saham terhadap likuiditas, terutama di pasar modal Indonesia.

Penelitian ini akan menggunakan pendekatan kuantitatif sebagaimana penelitian-penelitian sebelumnya. Metode yang akan digunakan adalah event study dimana pengujian akan dilakukan atas variabel yang sama yang dibandingkan antara sebelum dan sesudah terjadinya suatu peristiwa (event). Proksi variabel yang digunakan merupakan penggabungan dari berbagai proksi pada penelitian terdahulu agar dapat ditarik kesimpulan yang tepat.

Penelitian ini dilakukan untuk menggali mengenai pengaruh perubahan kebijakan kelompok harga dan fraksi harga saham terhadap likuiditas pasar modal di Indonesia. Tujuan penelitian ini adalah untuk menguji apakah perubahan kelompok harga dan fraksi harga saham tanggal 2 Mei 2016 di BEI mengakibatkan perubahan likuiditas pasar modal terutama terkait perdagangan saham. Penelitian ini juga akan menguji apakah perubahan likuiditas tersebut adalah sebuah peningkatan positif sesuai dengan tujuan pemberlakuan kebijakan.

\section{METODE PENELITIAN}

Penelitian ini dilakukan atas seluruh saham yang tercatat di Bursa Efek Indonesia (BEI) pada tahun 2016 yang berada pada event window penelitian. Periode dipilih dalam rentang waktu 40 hari bursa sebelum tanggal implementasi kebijakan perubahan fraksi harga atau event date, yaitu tanggal 2 Mei 2016 dan 40 hari setelah minggu pertama implementasi kebijakan, yaitu 6 Mei 2016. Minggu dimana terjadi perubahan kebijakan, yaitu tanggal 2-6 Mei 2016, tidak diikutsertakan kedalam sampel karena merupakan waktu transisi bagi pelaku pasar dalam mengubah perilakunya (Goldstein dan Kavajecz, 2000).

Periode pengamatan atau event window tidak boleh terlalu panjang untuk menghindari terjadinya confounding effect yang dapat menyebabkan likuiditas saham terpengaruh oleh peristiwa lain (Endri, 2016). Event window juga tidak boleh terlalu singkat sehingga tidak mendapatkan hasil yang bias (Oler et al. 2008). Menurut Oler et al. (2008), menggunakan event window yang terlalu singkat untuk suatu event yang jarang terjadi dapat menghasilkan kesimpulan yang bias, terutama di pasar yang kurang efisien. Tidak ada konsensus mengenai panjang periode event window, maka penelitian ini mengikuti event window penelitian-penelitian sebelumnya, yaitu 40 hari sebelum hingga 40 hari sesudah event date (Gambar 1).

Data yang digunakan dalam penelitian ini adalah data sekunder. Sumber pengambilan data adalah dari Bloomberg dan BEI. Selanjutnya, dari seluruh saham tersebut dipilih sejumlah sampel dengan menggunakan metode purposive sampling. Dari keseluruhan saham pada event window dipilih sejumlah sampel yang memenuhi kriteria pemilihan sampel, yaitu saham dari perusahaan yang selama periode penelitian: (1) tercatat di papan utama dan diperdagangkan di pasar reguler, (2) secara rata-rata diperjualbelikan lebih dari satu kali (3) tidak memiliki volume jual (offer volume) dan volume beli (bid volume) sebanyak nol (4) tidak melakukan penghapusan pencatatan (delisting) dan pemecahan saham (stock split) (5) tidak melakukan aksi korporasi (corporate action) seperti pengumuman pembagian deviden, penerbitan obligasi, penerbitan saham baru, dan lain-lain. Saham yang memiliki bid volume dan ask volume nol dikeluarkan dari sampel untuk menghindari terjadinya data error (Endri, 2016). Saham dari perusahaan yang melakukan delisting, stock split, dan corporate action lainnya dikeluarkan dari sampel untuk menghindari terjadinya confounding effect (Purwoto, 2003). 


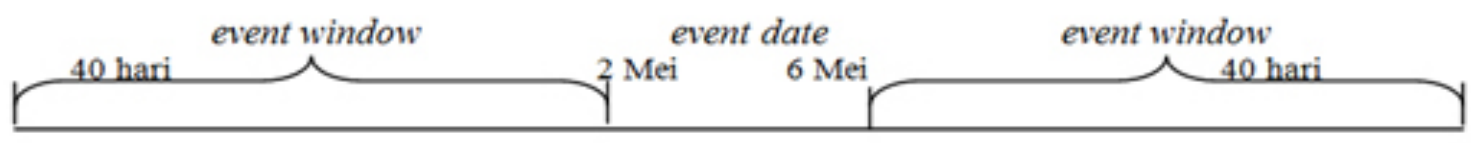

Gambar 1. Event window penelitian

Dalam penelitian ini, likuiditas saham perusahaan dianalisis dengan menggunakan tiga parameter (proxy), yaitu bid-ask spread, market depth dan trading volume. Bid-ask spread merupakan selisih antara harga beli tertinggi (bid price) dimana pelaku pasar bersedia untuk membeli suatu saham dan harga jual terendah (ask price) dimana pelaku pasar bersedia untuk menjual saham tersebut. Bid-ask spread mencerminkan biaya yang ditanggung oleh pelaku pasar untuk memperjualbelikan saham dengan cepat (Aitken dan Forde, 2003). Penelitian ini menggunakan relative bidask spread karena tidak mengandung unit mata uang dan lebih mudah untuk membandingkan dengan pasar internasional yang memiliki perbedaan mata uang (Ekaputra dan Ahmad, 2007). Adapun rumus untuk menghitung relative bid-ask spread adalah sebagai berikut:

$$
\text { Relative Spread } \text { Sp,t }=\frac{A_{j, t}-B_{j, t}}{\left(A_{j, t}+B_{j, t}\right) / 2}
$$

Dimana: Relative Spread $_{\mathrm{j}, \mathrm{t}}$ (relative bid-ask spread saham j pada waktu $\mathrm{t}$ ); $\mathrm{A}_{\mathrm{j}, \mathrm{t}}$ (harga jual terendah yang ditawarkan untuk saham $\mathrm{j}$ pada waktu $\mathrm{t}$ ); $\mathrm{B}_{\mathrm{j}, \mathrm{t}}$ (harga beli tertinggi yang diminta untuk saham $j$ pada waktu $t$ ).

Market depth merupakan parameter kedua untuk menganalisis likuiditas saham perusahaan yang mencerminkan seberapa besar suatu saham dapat menyerap nilai transaksi sebelum mempengaruhi harga (Ekaputra dan Ahmad, 2007). Untuk menganalisis market depth, digunakan data volume pengajuan beli dan volume pengajuan jual di akhir hari perdagangan (end of day bid depth and ask depth). Mengikuti Aitken dan Forde (2003), akan digunakan relative bid depth dan relative ask depth, dimana volume bid harian dan volume ask harian dalam lembar dibagi dengan total lembar saham yang tersedia untuk diperdagangkan (outstanding).

$$
\begin{aligned}
& \text { Relative Bid Depth }{ }_{\mathrm{j}, \mathrm{t}}=\text { Bid } \mathrm{Vol}_{\mathrm{j}, \mathrm{t}} / \mathrm{S}_{\mathrm{j}, \mathrm{t}} \\
& \text { Relative Ask Depth } h_{\mathrm{j}, \mathrm{t}}=A s k \mathrm{Vol}_{\mathrm{j}, \mathrm{t}} / \mathrm{S}_{\mathrm{j}, \mathrm{t}}
\end{aligned}
$$

Dimana: Relative Bid Depth ${ }_{\mathrm{j}, \mathrm{t}}$ (Relative bid depth saham j pada waktu t); Relative Ask Depth ${ }_{\mathrm{j}, \mathrm{t}}$ (Relative ask depth saham $\mathrm{j}$ pada waktu $\mathrm{t}$ ); Bid $\mathrm{Vol}_{\mathrm{j}, \mathrm{t}}$ (Jumlah volume (lembar) bid saham j pada waktu t); Ask $\mathrm{Vol}_{\mathrm{j}, \mathrm{t}}$ (Jumlah volume (lembar) ask saham j pada waktu $\mathrm{t}$ ); $\mathrm{S}_{\mathrm{j}, \mathrm{t}}$ (Total lembar saham $\mathrm{j}$ tersedia pada waktu $\mathrm{t}$ ).

Trading volume adalah parameter ketiga untuk mengukur likuiditas saham perusahaan yang mencerminkan banyaknya suatu saham diperjualbelikan atau ditransaksikan dalam suatu periode tertentu. Trading volume terdiri dari volume jual dan volume beli. Dalam penelitian ini, data trading volume per hari digunakan untuk menganalisis likuiditas saham. Mengikuti Aitken dan Forde (2003) dan Lo dan Wang (2009), akan digunakan relative volume, dimana volume transaksi harian dalam lembar dibagi dengan total lembar saham yang tersedia untuk diperdagangkan (outstanding).

$$
\text { Relative } \mathrm{Vol}_{\mathrm{j}, \mathrm{t}}=\mathrm{V}_{\mathrm{j}, \mathrm{t}} / \mathrm{S}_{\mathrm{j}, \mathrm{t}}
$$

Dimana: Relative $\mathrm{Vol}_{\mathrm{j}, \mathrm{t}}$ (Relative volume saham $\mathrm{j}$ pada waktu t); $\mathrm{V}_{\mathrm{j}, \mathrm{t}}$ (Jumlah volume (lembar) perdagangan saham $\mathrm{j}$ pada waktu $\mathrm{t}$ ); $\mathrm{S}_{\mathrm{j}, \mathrm{t}}$ (Total lembar saham $\mathrm{j}$ tersedia pada waktu t).

Penelitian ini menggunakan pendekatan kuantitatif dan metode studi peristiwa (event study) untuk menganalisis dampak dari implementasi kebijakan baru mengenai perubahan kelompok harga dan fraksi harga oleh BEI terhadap likuiditas saham. Dalam hal ini, dilakukan pengujian apakah terdapat perubahan likuiditas setelah adanya kebijakan baru. Pada awalnya, metode event study dipergunakan untuk mengidentifikasi dampak dari suatu peristiwa tertentu terhadap harga saham di pasar modal yang dapat menciptakan terjadinya abnormal return (Mackinlay, 1997). Namun demikian, pendekatan ini juga banyak dipergunakan untuk menguji kandungan informasi dari suatu peristiwa terhadap variabel selain harga saham. Secara umum, pendekatan dan metode penelitian yang digunakan bertujuan mengetahui apakah terdapat perbedaan likuiditas saham pada saat sebelum dan setelah implementasi kebijakan perubahan fraksi harga. 
Penelitian ini menggunakan metode pengujian parametrik dengan uji-t (parametric t-test) karena jumlah sampel yang cukup besar sehingga diharapkan dapat memenuhi asumsi distribusi normal. Menurut central limit theorem, jumlah sampel lebih dari 30 membuat distribusi data mendekati normal. Uji-t dilakukan untuk membandingkan rata-rata dari dua kelompok sampel yang saling tidak berhubungan (independent samples) (Lind, 2008). Pengelompokan sampel dibedakan menurut dua kelompok waktu, yaitu sebelum dan setelah implementasi kebijakan. Hasil uji-t menghasilkan angka yang kemudian dibandingkan dengan nilai t-statistik untuk mendapat kesimpulan apakah rata-rata variabel penelitian yang diuji terdapat perbedaan signifikan, dan jika ada apakah perbedaan tersebut dapat dilihat apakah berupa perubahan positif atau perubahan negatif.

Penelitian oleh Harris (1994), Ting Lau dan McInish (1995), Goldstein dan Kavajecz (2000), Ekaputra dan Ahmad (2007) dan Endri (2016) menemukan bahwa penurunan fraksi harga saham mengakibatkan penurunan bid-ask spread. Bessembinder (2000) menemukan bahwa saham dengan fraksi harga lebih kecil memiliki bid-ask spread yang lebih rendah. Hal ini menunjukkan bahwa fraksi harga dan bid-ask spread memiliki hubungan searah, maka penelitian ini menggunakan hipotesis berikut terkait pengukuran likuiditas menggunakan bid-ask spread.

H1: Bid-ask spread setelah kebijakan perubahan kelompok harga dan fraksi harga saham lebih besar daripada sebelum perubahan kebijakan.

Goldstein dan Kavajecz (2000) dan Ekaputra dan Ahmad (2007) menemukan terdapat penurunan marketdepth setelah penurunan fraksi harga saham. Penurunan market-depth menandakan penurunan likuiditas saham.
Oleh karena itu, penelitian ini menggunakan hipotesis berikut terkait pengukuran likuiditas menggunakan market depth.

H2: Market depth setelah kebijakan perubahan kelompok harga dan fraksi harga saham lebih besar daripada sebelum perubahan kebijakan.

Aitken dan Forde (2005), Ahn et al. (2007) dan Endri (2016) menemukan bahwa volume perdagangan saham tidak mengalami kenaikan yang signifikan setelah terjadinya penurunan fraksi harga. Hal tersebut menandakan tidak terdapatnya perubahan likuiditas saham. Oleh karena itu, penelitian ini menggunakan hipotesis berikut terkait pengukuran likuiditas menggunakan volume perdagangan.

H3: Volume perdagangan setelah kebijakan perubahan kelompok harga dan fraksi harga saham tidak mengalami perubahan signifikan daripada sebelum perubahan kebijakan.

Penelitian ini membandingkan likuditas pasar saham pre-event date dan post-event date, dimana event yang dimaksud adalah perubahan kelompok harga dan fraksi harga saham terhitung mulai tanggal 2 Mei 2016. Kerangka pemikiran penelitian dapat dilihat pada Gambar 2. Pengukuran likuditas dilakukan dengan menggunakan parameter bid-ask spread, market depth dan trading volume. Masing-masing parameter ini diwakili proksinya kemudian dibandingkan antara sebelum dan sesudah perubahan kebijakan dengan uji beda t-test. Dari hasil uji tersebut dapat ditarik kesimpulan apakah terdapat perbedaan likuiditas pasar saham antara sebelum dan sesudah perubahan kebijakan dan jika terdapat perbedaan apakah terjadi peningkatan atau penurunan.

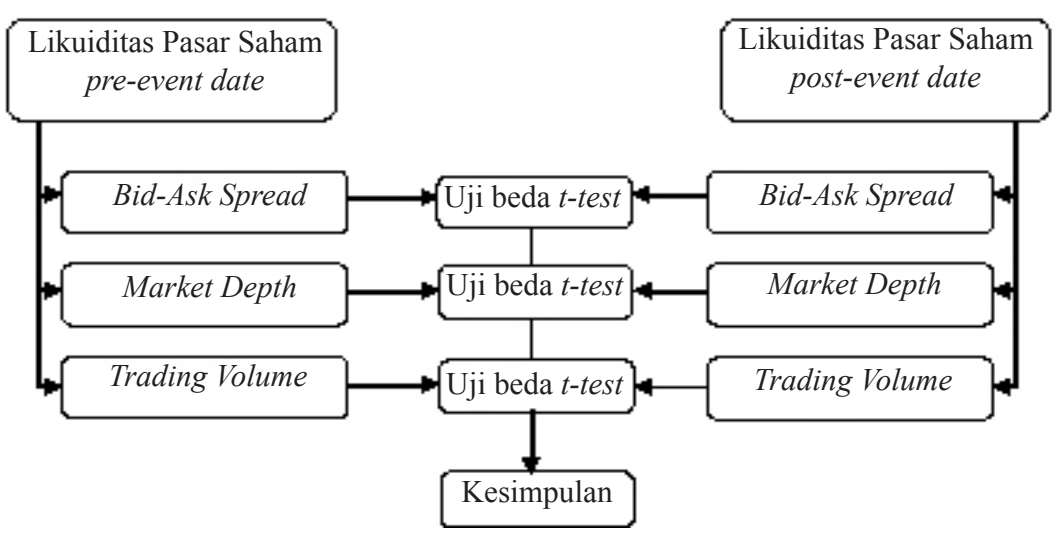

Gambar 2. Kerangka pemikiran penelitian 


\section{HASIL}

\section{Statistik Deskriptif}

Pertama, telah dilakukan pengumpulan data atas seluruh saham di BEI berupa bid price, bid volume, ask price, ask volume, trading volume dan outstanding saham pada tanggal 3 Maret 2016 sampai dengan 29 April 2016 (40 hari kerja periode sebelum perubahan kebijakan) dan 9 Mei 2016 hingga 4 Juli 2016 (40 hari kerja periode setelah kebijakan). Setelah mengeluarkan sampel perusahaan yang tidak memiliki perdagangan dan melakukan corporate action maka didapat 211 sampel perusahaan yang datanya diolah untuk mengetahui apakah terdapat perubahan likuiditas perdagangan di BEI setelah perubahan kebijakan fraksi dan harga saham.

Dapat dilihat pada Tabel 2 untuk rata-rata relative volume sebelum dan sesudah kebijakan mengalami penurunan dari 0,00147 menjadi 0,00124 . Untuk variabel bid-askjuga mengalami penurunan dari 0,00899 menjadi 0,00868 . Demikian juga untuk variabel ask depth mengalami penurunan dari 7,57 x 10-5 menjadi $5,13 \times 10-5$. Hanya variabel bid depth yang terlihat mengalami kenaikan dari 5,98 x 10-5 menjadi $6,12 \times$ 10-5. Untuk nilai minimum adalah 0 terjadi karena ada saham yang tidak memiliki transaksi di hari tertentu. Untuk nilai maksimum, variabel bid-ask dan bid depth terlihat terjadi kenaikan, sedangkan untuk variabel relative volume dan ask depth mengalami penurunan. Namun statistik deskriptif ini tidak dapat membuktikan terjadinya kenaikan atau penurunan likuiditas di perdagangan pasar modal dan harus diuji apakah kenaikan atau penurunan yang ada bersifat signifikan, yaitu apakah nilai rata-rata secara statistik memiliki perbedaan antara sebelum dan setelah kebijakan.

\section{Hasil Uji-t}

Setelah melakukan uji beda dari rata-rata keempat variabel sebelum dan sesudah kebijakan, hasilnya dapat dilihat pada Tabel 4. Dari hasil uji t-test atas 211 sample perusahaan, terlihat bahwa nilai t-test untuk keempat variabel memiliki nilai yang tidak signifikan, sehingga dapat disimpulkan bahwa tidak terjadi perubahan rata-rata variabel yang signifikan sebelum dan setelah permberlakuan kebijakan. Hal ini menandakan bahwa tingkat likuiditas perdagangan di pasar modal tidak mengalami perubahan.

Secara keseluruhan tidak terdapat perbedaan tingkat likuiditas perdagangan di pasar modal yang signifikan pada sebelum dan setelah pemberlakuan kebijakan, penulis ingin menguji apakah dalam kelompok harga tertentu terdapat perubahan tingkat likuiditas yang signifikan dikarenakan terdapatnya fraksi harga saham yang berbeda dari sebelumnya. Maka kemudian dilakukan pengelompokkan harga saham atas 211 sample perusahaan tersebut sesuai dengan kebijakan kelompok harga terbaru selama periode penelitian, dengan sebelumnya mengeluarkan sampel saham perusahaan yang mengalami perpindahan kelompok harga selama periode penelitian. Terdapat 162 sampel perusahaan untuk melihat perbedaan likuiditas di dalam kelompok harga saham.

Hasil ujit-test beda rata-rata untuk kelompok-kelompok harga saham dapat dilihat pada Tabel 3. Sesuai dengan hasil keseluruhan, tidak ada rata-rata variabel yang berbeda secara signifikan pada hasil uji di kelompok harga kurang dari Rp200. Begitu juga pada kelompok harga-kelompok harga berikutnya, tidak ada variabel yang terbukti mengalami kenaikan atau penurunan rata-rata yang signifikan.

Tabel 2. Statistik deskriptif variabel

\begin{tabular}{lcccccccc}
\hline & \multicolumn{3}{c}{ Sebelum Kebijakan } & \multicolumn{3}{c}{ Setelah Kebijakan } \\
\hline Variabel & Mean & Median & Min & Max & Mean & Median & Min & Max \\
\hline Relative Bid-Ask & 0,00899 & 0,00427 & 0,00025 & 0,08795 & 0,00868 & 0,00413 & 0,00039 & 0,09696 \\
Relative Bid Depth & $5,98 \times 10-5$ & $3,63 \times 10-5$ & 0 & 0,00928 & $6,12 \times 10-5$ & $3,83 \times 10-5$ & 0 & 0,01376 \\
Relative Ask Depth & $7,57 \times 10-5$ & $8,34 \times 10-5$ & 0 & 0,01663 & $5,13 \times 10-5$ & $7,35 \times 10-5$ & 0 & 0,01309 \\
Relative Volume & 0,00147 & $3,88 \times 10-5$ & 0 & 0,21314 & 0,00124 & $2,72 \times 10-5$ & 0 & 0,12543 \\
\hline
\end{tabular}


Tabel 4. Hasil uji beda rata-rata

\begin{tabular}{lccl}
\hline Variabel & $\mathrm{t}$-test & $\mathrm{df}$ & Hasil Uji-t \\
\hline Relative BID-ASK (All) & 0,221 & 420 & Tidak signifikan \\
Relative BID Depth (All) & $-0,101$ & 420 & Tidak signifikan \\
Relative ASK Depth (All) & 1,126 & 259 & Tidak signifikan \\
Relative Volume (All) & 0,612 & 363 & Tidak signifikan \\
\hline
\end{tabular}

Tabel 4. Hasil Uji Beda Rata-Rata Kelompok Harga

\begin{tabular}{lccl}
\hline Variabel & t-test & df & Hasil Uji-t \\
\hline Kelompok Harga $>$ Rp200 & & \\
\hline Relative BID-ASK & 0,004 & 168 & Tidak signifikan \\
Relative BID Depth & $-0,351$ & 160 & Tidak signifikan \\
Relative ASK Depth & 0,217 & 167 & Tidak signifikan \\
Relative Volume & $-0,034$ & 165 & Tidak signifikan \\
\hline Kelompok Harga Rp200 - < Rp500 & \\
\hline Relative BID-ASK & 0,119 & 50 & Tidak signifikan \\
Relative BID Depth & $-0,710$ & 49 & Tidak signifikan \\
Relative ASK Depth & 0,782 & 27 & Tidak signifikan \\
Relative Volume & 0,105 & 50 & Tidak signifikan \\
\hline Kelompok Harga Rp500 - < Rp2.000 & \\
\hline Relative BID-ASK & 0,237 & 74 & Tidak signifikan \\
Relative BID Depth & $-0,011$ & 74 & Tidak signifikan \\
Relative ASK Depth & 0,391 & 74 & Tidak signifikan \\
Relative Volume & $-0,333$ & 70 & Tidak signifikan \\
\hline Kelompok Harga Rp2.000 - < Rp5.000 & \\
\hline Relative BID-ASK & $-0,411$ & 10 & Tidak signifikan \\
Relative BID Depth & $-0,633$ & 9 & Tidak signifikan \\
Relative ASK Depth & 1,704 & 8 & Tidak signifikan \\
Relative Volume & $-0,413$ & 9 & Tidak signifikan \\
\hline Kelompok Harga $>$ Rp5.000 & & \\
\hline Relative BID-ASK & $-0,392$ & 7 & Tidak signifikan \\
Relative BID Depth & $-0,788$ & 6 & Tidak signifikan \\
Relative ASK Depth & 0,526 & 6 & Tidak signifikan \\
Relative Volume & 0,017 & 8 & Tidak signifikan \\
\hline
\end{tabular}

Dari hasil perhitungan yang telah dilakukan maka didapat jawaban atas hipotesis yang telah dibangun. Hipotesis 1 yang menyatakan bahwa bid-ask spread setelah kebijakan perubahan kelompok harga dan fraksi harga saham lebih besar daripada sebelum perubahan kebijakan, tidak terbukti dan didapatkan bahwa bid-ask spread setelah kebijakan perubahan kelompok harga dan fraksi harga tidak berbeda secara signifikan dengan sebelum kebijakan. Hipotesis 2 yang menyatakan bahwa market depth setelah kebijakan perubahan kelompok harga dan fraksi harga saham lebih besar daripada sebelum perubahan kebijakan, tidak terbukti dan didapatkan bahwa baik bid depth maupun ask depth setelah kebijakan perubahan kelompok harga dan fraksi harga tidak berbeda secara signifikan dengan sebelum kebijakan. Hipotesis 3 yang menyatakan bahwa volume perdagangan setelah kebijakan perubahan kelompok harga dan fraksi harga saham tidak mengalami perubahan signifikan daripada sebelum perubahan kebijakan, terbukti dan didapatkan bahwa volume perdagangan setelah kebijakan perubahan kelompok harga dan fraksi harga tidak berbeda secara signifikan dengan sebelum kebijakan.

Hal ini menandakan bahwa pasar tidak bereaksi atas perubahan kebijakan, dan perubahan fraksi harga dan kelompok harga saham tidak memiliki pengaruh pada investor di pasar modal terkait likuiditas perdagangan. HasilpenelitiansesuaidenganhasilpenelitianBourghelle dan Declerck (2004) yang meneliti perubahan fraksi harga di Paris dimana terdapat kenaikan dan penurunan fraksi harga bersamaan pada kelompok harga berbeda juga menemukan tidak terdapat perubahan likuiditas dikur dengan tidak adanya perubahan biaya eksekusi. Menurut Bourghelle dan Declerck (2004) meskipun likuiditas tidak mengalami perubahan namun terdapat peningkatan transparansi likuiditas penawaran.

Penelitian Kadan (2006) memberikan informasi bahwa perubahan fraksi harga akan memberikan pengaruh yang berbeda bagi pasar modal dengan jenis investor yang berbeda. Ketika jumlah dealer atau investor institusi cukup besar, investor mengharapkan fraksi harga yang besar, karena mengaharapkan keuntungan yang lebih besar. Sebaliknya, ketika investor individual lebih mendominasi, investor lebih mengharapkan fraksi harga yang kecil, menandakan biaya jual beli yang lebih rapat dan minimum. Investor institusional di Indonesia mendominasi sebesar 73,14\% di Maret 2015 (Pasopati, 2015). Hal ini menandakan pemerintah mengakomodasi investor institusional dalam perubahan fraksi harga dan kelompok harga, sebagaimana permintaan pelaku pasar modal (Indrastiti, 2015).

\section{Implikasi Manajerial}

Hasil penelitian menunjukkan tidak terdapatnya perubahan berupa peningkatan likuiditas di pasar saham atas kebijakan perubahan kelompok harga dan fraksi harga saham. Hal ini menandakan terdapatnya perubahan reaksi investor atas suatu kebijakan yang sama yang dilakukan sebelumnya. Pemerintah, dalam hal ini melalui BEI, dapat mencari solusi untuk membuat kebijakan yang berbeda agar tujuan peningkatan likuiditas perdagangan di pasar modal dapat tercapai. 


\section{KESIMPULAN DAN SARAN}

\section{Kesimpulan}

Hasil penelitian menemukan tidak terbukti adanya perubahan rata-rata variabel relative volume, bidask, bid depth maupun ask depth yang signifikan Dari temuan tersebut dapat disimpulkan bahwa tidak terdapat peningkatan likuiditas perdagangan di pasar modal setelah kebijakan perubahan kelompok harga dan fraksi harga terhitung mulai tanggal 2 Mei 2016. Hasil ini bertentangan dengan penelitian sebelumnya, terutama penelitian kebijakan tahun 2014 di Indonesia yang dilakukan oleh Irawan dan Suaryana (2016) dan Endri (2016). Namun, penelitian memiliki kesamaan dengan hasil penelitian Bourghelle dan Declerck (2004) di Paris yang menemukan bahwa perubahan fraksi harga baik penurunan maupun kenaikan tidak menghasilkan perubahan likuiditas.

\section{Saran}

Hasil penelitian iniberbeda dengan penelitian-penelitian sebelumnya di Indonesia dimana pada kebijakan sebelumnya didapatkan reaksi peningkatan bid-ask spread maupun market depth meskipun tidak diikuti perubahan volume perdagangan. Penelitian Kadan (2006) berfokus kepada pertambahan kekayaan investor dan bukan terhadap likuiditas. Hal ini dapat menjadi bahan penelitian berikutnya untuk menambahkan informasi lebih lengkap mengenai dampak perubahan fraksi dan kelompok harga terhadap investor terutama pada perbedaan investor institusi dan investor individu. Dapat dipertimbangkan mengenai jumlah investor institusi yang jauh melampaui investor individual yang menyebabkan kebijakan dapat berdampak berbeda, dimana di pasar modal lain di dunia investor individu memiliki jumlah cukup signifikan. Selain itu faktor efisiensi pasar juga perlu dipertimbangkan terkait dengan daya saing pasar global. Syauqi et al. (2018) juga menemukan bahwa efisiensi anggota bursa di Indonesia masih rendah dan perlu ditingkatkan agar daya saing pasar modal di Indonesia dapat meningkat.

\section{DAFTAR PUSTAKA}

Ahn HJ, Cai J, Chan K, Hamao Y. 2007. Tick size change and liquidity provision on the Tokyo Stock Exchange. Journal of the Japanese and International Economies 21: 173-194. https:// doi.org/10.1016/j.jjie.2005.10.008.

Aitken M, Comerton-Forde C. 2005. Do reductions in tick sizes influence liquidity? Accounting and Finance 45(2): 171-184. https://doi.org/10.1111/ j.1467-629x.2004.00128.x.

Aitken M, Comerton-Forde C. 2003. How Should Liquidity be Measured? Pacific-Basin Finance Journal 11(1): 45-59. https://doi.org/10.1016/ S0927-538X(02)00093-8.

Aliya A. 2016. BEI Terapkan Besaran Fraksi Baru. https://finance.detik.com/bursa-valas/3200275/ bei-terapkan-besaran-fraksi-harga-baru. [29April 2016].

Berkowitz SA, Logue DE, Noser EA. 1988. The total costs of transacting on the NYSE. The Journal of Finance 43(1): 97-112. https://doi.org/10.1111/ j.1540-6261.1988.tb02591.x.

Bessembinder H. 2000. Tick size, spreads, and liquidity: An analysis of Nasdaq securities trading near ten dollars. Journal of Financial Intermediation 9: 213-239. https://doi. org/10.1006/jfin.2000.0288.

Bourghelle D, Declerck F. 2004. Why markets should not necessarily reduce the tick size. Journal of Banking \& Finance 28: 373-398. https://doi. org/10.1016/S0378-4266(03)00136-5.

[BEI] Bursa Efek Indonesia. 2016. Peraturan Nomor II-A tentang Perdagangan Efek Bersifat Ekuitas Nomor: Kep-00023/BEI/04-2016. Jakarta: Bursa Efek Indonesia.

Ekaputra IA, Ahmad B. 2007. The impact of tick size reduction on liquidity and order strategy: Evidence from the Jakarta Stock Exchange (JSX). Economics and Finance in Indonesia 55: 89-104. https://doi.org/10.7454/efi.v55i1.110.

Endri. 2016. Dampak perubahan satuan perdagangan dan fraksi harga terhadap likuiditas saham. Jurnal Ilmiah Manajemen 7(1): 56-69.

Goldstein M, Kavajecz K. 2000. Eights, sixteenth, and market depth: Changes in tick size and liquidity provision on NYSE. Journal of Financial Economics 56: 125-149. https://doi.org/10.1016/ S0304-405X(99)00061-6.

Harris L. 1994. Minimum price variation, discrete bidask spreads, and quotation sizes. The Review of Financial Studies 7: 149-178. https://doi. org/10.1093/rfs/7.1.149.

Harris L. 2003. Trading and exchanges: Market microstructure for practitioners. Oxford: Oxford University Press.

Hu G. 2009. Measures of implicit trading costs and 
buy-sell asymmetry. Journal of Financial Markets 12: 418-437. https://doi.org/10.1016/j. finmar.2009.03.002.

Indrastiti N.2015. Fraksi harga akan berubah lagi jadi lima kelompok. https://investasi.kontan.co.id/ news/fraksi-harga-akan-berubah-lagi-jadi-limakelompok. [10 Agustus 2015].

Irawan IKDDD, Suaryana IGNA. 2016. Perbandingan likuiditas saham sebelum dan sesudah perubahan fraksi harga dan satuan perdagangan. E-Jurnal Akuntansi Universitas Udayana 14: 1298-1325.

Kadan O. 2006. So who gains from a small tick size? Journal of Financial Intermediation 15: 32-66. https://doi.org/10.1016/j.jfi.2004.09.003.

Lau ST, Mcinish T. 1995. Reducing tick sizes on the Singapore Stock Exchange. Pacific-Basin Finance Journal 3: 485-496. https://doi. org/10.1016/0927-538X(95)00019-H.

Lo AW, Wang J. 2009. Handbook of Financial Econometrics: Applications, Vol. 2, 1st Edition, UK: Elsevier.

Lind DA, Marchal WG, Wathen SA. 2008. Statistical techniques in business \& economics. Boston:
McGraw-Hill.

Mackinlay C. 1997. Event studies in economics and finance. Journal of Economic Literature 35(1): $13-39$.

Pasopati IG. 2015. Bursa Saham Indonesia Masih Dikuasai Investor Institusi. https://www. cnnindonesia.com/ekonomi/2015042211063778-48363/bursa-saham-indonesia-masihdikuasai-investor-institusi. [22 April 2015].

Perold AF. 1988. The implementation shortfall: Paper versus reality. The Journal of Portfolio Management Spring 14(3): 4-9. https://doi. org/10.3905/jpm.1988.409150.

Porter D, Weaver D. 1997. Tick Size and Market Quality. Financial Management 26(4): 5-26. https://doi.org/10.2307/3666124.

Purwoto L. 2003. Perubahan Fraksi Harga di Bursa Efek Jakarta. Ventura 6(3): 235-252.

Syauqi MR, Hakim DB, Sasongko H. 2018. Efisiensi anggota bursa guna meningkatkan daya saing bisnis pada era masyarakat ekonomi ASEAN. Jurnal Aplikasi Manajemen dan Bisnis 4(2): 91-201. 